\title{
Local Modulation of Hippocampal Acetylcholine Release by Dopamine D1 Receptors: A Combined Receptor Autoradiography and in vivo Dialysis Study
}

\author{
Ali I. Hersi, ${ }^{1,3,4}$ Jean W. Richard, ${ }^{3}$ Pierrette Gaudreau, ${ }^{4}$ and Remi Quirion ${ }^{1,2,3}$ \\ Departments of ${ }^{1}$ Neurology/Neurosurgery and ${ }^{2}$ Psychiatry, McGill University, Montreal, Quebec, Canada, ${ }^{3}$ Douglas \\ Hospital Research Center, Verdun, Quebec, Canada, and ${ }^{4}$ Neuroendocrinology Laboratory, Hopital Notre Dame, \\ Universite de Montreal, Montreal, Quebec, Canada
}

The modulation of in vivo hippocampal ACh release by dopaminergic D1 and D2 receptors was examined in this study. Additionally, in an attempt to ascertaln the location of these receptors in relation to hippocampal cholinergic terminals, fimbriaectomy and quantitative autoradiography were used. Following unilateral fimbriaectomy, whereby at least $\mathbf{5 0 \%}$ of hippocampal cholineacetyltransferase (ChAT) activity was lost, a significant ipsilateral decrease in $\mathrm{D} 1 /^{3} \mathrm{H}$ SCH23390 binding was observed in the molecular layer of the dentate gyrus while hippocampal $\mathrm{D} 2 /{ }^{3} \mathrm{H}$ raclopride binding was unaffected. The effects of prototypical D1 and D2 receptor agonists and antagonists on hippocampal $\mathrm{ACh}$ release were examined next using in vivo dialysis in freely moving rats. The D1 agonist SKF 38393 (10 $\mu \mathrm{M}$ to $100 \mu \mathrm{M})$ administered directly into the hippocampus via the dialysis probe stimulated $\mathrm{ACh}$ release in a concentration dependent manner. The effect of the agonist was blocked by the coadministration of the D1 receptor antagonist SCH 23390 $(1 \mu \mathrm{M})$, which by itself failed to modulate $\mathrm{ACh}$ release. In contrast, neither the $\mathrm{D} 2$ agonist quinpirole (1-10 $\mu \mathrm{M})$ nor the D2 antagonist sulpiride (1-10 $\mu \mathrm{M}$ ) had any direct effect on hippocampal $\mathrm{ACh}$ release. Additionally, the infusion of these D1 and D2 drugs in the septal area failed to affect hippocampal ACh release. Taken together, these results suggest that a proportion of hippocampal D1 receptors are located on cholinergic nerve terminals and that dopamine, acting via D1 receptors, can locally stimulate hippocampal ACh release.

[Key words: ACh, dopamine, hippocampus, in vivo dialysis, receptor autoradiography, D1 receptor]

Dopamine (DA) is thought to modulate the activity of the septohippocampal cholinergic pathway (Robinson et al., 1979; Costa et al., 1983). Infusions of dopamine antagonists into the septum increase the firing rate of this pathway (Robinson et al., 1979) and elevate ACh turnover (Robinson et al., 1979) and high affinity choline uptake (Durkin el al., 1986) in the hippocampus.

\footnotetext{
Received Apr. 7, 1995; revised June 14, 1995; accepted June 15, 1995

This work was supported by a grant from the Medical Research Council of Canada (MRCC) to R.Q., a Chercheur Boursier Senior of the Fonds de la Recherche en Sante du Quebec (FRSQ). A.H. is a holder of a studentship from FRSQ. P.G. holds a Chercheur-Boursier award from FRSQ.

Correspondence should be addressed to Dr. Remi Quirion, Douglas Hospital Research Center, 6875 Boulevard Lasalle, Verdun, Quebec, Canada H4H IR3. Copyright $\mathcal{C} 1995$ Society for Neuroscience $0270-6474 / 95 / 157150-08 \$ 05.00 / 0$
}

Similar effects are also observed following either intraseptal 6-hydroxydopamine injection (Robinson et al., 1979) or the destruction of the ventral tegmental Al0 dopaminergic neurons (Robinson et al., 1979; Galey et al., 1985). It has been suggested that $\mathrm{A} 10$ dopaminergic neurons projecting to the lateral septum interact with cholinergic fibers originating from the medial septal nucleus, possibly via septal GABAergic interneurons, to bring about this inhibitory influence (Wood, 1985). On the other hand, a variety of wide ranging studies including morphological (Scatton et al., 1980; Verney et al., 1985; Simon et al., 1989), electrophysiological (Gribkoff et al., 1984; Stanzione et al., 1984; Smialowski et al., 1987) and biochemical (Bischoff, 1979; Ishikawa, 1982) approaches provide evidence suggesting that the hippocampus receives direct dopaminergic innervation. This innervation apparently originates mainly from the ventral tegmental area (VTA; and to a lesser extent from the substantia nigra) and ascends in the medial forebrain bundle to innervate various limbic structures, including the hippocampus (Verney et al., 1985).

Dopamine receptors have been classified in two broad families (D1-like and D2-like) on the basis of the activity of various agonists and antagonists (Kebabian and Calne, 1979; Seeman, 1980). More recently, molecular cloning techniques have shown that the D1 family comprises two receptors (d1 and d5) while the D2 family consists of at least three different receptor proteins (d2, d3, and d4) (for a recent review, see Niznik and Van Tol, 1992). D1 receptors activate adenylate cyclase whereas members of the D2 receptor class have been shown to couple to numerous effector systems, including the inhibition of adenylate cyclase and the activation of potassium channels, among others (Monsma et al., 1990; Sibley and Monsma, 1992). Both the D1 and the D2 receptor subtypes have been localized in the septum as well as the hippocampus of various mammalian species including the rat (Bischoff et al., 1980; Bruink et al., 1986; Dawson et al., 1986; Grilli et al., 1988; Tiberi et al., 1991; Mengod et al., 1992).

Given this background, it is thus likely that dopamine may act as a modulator of the septo-hippocampal cholinergic pathway hoth at the level of the cell bodies in the septal area and at the nerve terminals within the hippocampus. In the present study, these two possibilities were investigated directly by examining the effects of local administration of selective dopamine D1 and D2 receptor agonists and antagonists on hippocampal ACh release using in vivo dialysis in freely moving rats as well as by evaluating the effects of unilateral fimbriaectomy on these 
receptors in the hippocampus as monitored by quantitative autoradiography. Our results suggest that a certain proportion of pharmacologically defined D1 receptors are located on cholinergic nerve terminals and that dopamine may act, via D1 receptors, as a stimulatant of $\mathrm{ACh}$ release at level of the cholinergic nerve terminals within the hippocampus.

\section{Materials and Methods}

Materials. Male Sprague-Dawley rats $(250-350 \mathrm{gm})$ obtained from Charles River Canada (St. Constant, Quebec, Canada) were maintained on a 12 hr light-dark cycle (light on at 7:00 A.M.) in temperature and humidity controlled rooms for at least $3-4$ d prior to surgery. Animals were fed standard laboratory chow and had access to tap water ad libitum. Animal care was according to protocols and guidelines approved by the McGill University Animal Care Committee and the Canadian Council for Animal Care (CCAC).

The dialysis probes were made from AN69 Hospal fibers (molecular weight cut off $<60,000$ i.d. $=220 \mu \mathrm{m}$, o.d. $=310 \mu \mathrm{m})$. SCH 23390 $\mathrm{HCl},(+)$ SKF $38393 \mathrm{HCl},(-) \mathrm{SKF} 38393 \mathrm{HCl}$, quinpirole $\mathrm{HCl}$, sulpiride, and eticlopride $\mathrm{HCl}$ were obtained from RBI (Watick, MA). Neostigmine Bromide was purchased from BAS (West Lafayette, IN). ${ }^{3} \mathrm{H}$ SCH23390 $(80.7 \mathrm{Ci} / \mathrm{mmol}),{ }^{3} \mathrm{H}$ raclopride $(70.0 \mathrm{Ci} / \mathrm{mmol})$, ${ }^{3} \mathrm{H}-\mathrm{Hyper}-$ films and microscale standards were purchased from Amersham Canada (Oakville, Ontario, Canada). The deuterated variant of $\mathrm{ACh},{ }^{2} \mathrm{H}_{4} \mathrm{ACh}$ bromide $\left[\left(\mathrm{CH}_{3}\right)_{3} \mathrm{NBrCD}\right.$ CD, OC- $\left.(0) \mathrm{CH}_{3}\right]$, used as internal standard for ACh determination was obtained from Merck, Sharp and Dohme Isotopes (Montreal, Quebec, Canada). Developer (D-19) and fixer (Rapid Fix) were obtained from Kodak Chemical Inc. (Montreal, Quebec, Canada). All other reagents and chemicals were of HPLC or GC-MS grade and purchased from either Fisher Scientific Co. (Montreal, Quebec, Canada) or Aldrich Chemicals (Chicago, IL).

Fimbriaectomy. The fimbria fornix of male rats was unilaterally interrupted by a knife cut lesion under sodium nembutal anesthesia $(50$ $\mathrm{mg} / \mathrm{kg}$ ). Briefly, at a $90^{\circ}$ angle and coordinates of $1 \mathrm{~mm}$ behind bregma and $3.0 \mathrm{~mm}$ lateral to the midline suture (Paxinos and Watson, 1982), a leukotome knife (Kopf Instruments) was lowered via an opening in the skull to a depth of $4.0 \mathrm{~mm}$ below dura. The wire in the knife was then extended under the fimbria and the leukotome slowly brought back to the dura. For sham operated animals, the leukotome was lowered and brought back to the surface as above but without extending the wire. The animals were allowed to recover from anesthesia under a warm light and individually housed according to CCAC guidelines. Two weeks postsurgery, the animals were sacrificed and the efficacy of the lesions was assessed by determining hippocampal ChAT activity.

Hippocampal ChAT activity. Hippocampal punches from $300 \mu \mathrm{m}$ brain slices of the lesioned and sham operated animals were assayed for ChAT activity. Homogenates from these punches were incubated for $15 \mathrm{~min}$ in a buffer containing ${ }^{1+} \mathrm{C}$ acetyl $\mathrm{CoA}$ as previously described in detail (Araujo et al., 1988) using the method of Fonnum (1969) as modified by Tucek (1978). The animals that were used in subsequent receptor autoradiographic studies showed hippocampal ChAT activity losses of $51 \pm 4 \%$ on the lesioned side as compared to the contralateral hippocampi.

Dopamine receptor autoradiography. The status of hippocampal dopaminergic receptors following fimbriaectomy was assessed as described in detail elsewhere (Debonnel et al., 1990). In brief, following sectioning at $-17^{\circ} \mathrm{C}, 20 \mu \mathrm{m}$ hippocampal slices were incubated for 60 min at room temperature in $50 \mathrm{~mm}$ Tris $H C L$ buffer $(\mathrm{pH} 7.4)$ containing $120 \mathrm{~mm} \mathrm{NCl}, 5 \mathrm{~mm} \mathrm{KCl}, 2 \mathrm{mM} \mathrm{CaCl}, 1 \mathrm{mM} \mathrm{MgCl}_{2}$, and $1.0 \mathrm{~nm}{ }^{3} \mathrm{H}$ $\mathrm{SCH} 23390$ for D1 receptors or $5.7 \mathrm{nM}{ }^{3} \mathrm{H}$ raclopride for $\mathrm{D} 2$ receptors. Serial sections were incubated in this buffer but with the addition of 1 $\mu \mathrm{M} \mathrm{SCH} 23390$ or $1 \mu \mathrm{M}(+)$ butaclamol to ascertain the specificity of the D1 or D2 radioligand binding, respectively. The sections were then rinsed five times ( $2 \mathrm{~min}$ each) in fresh ice-cold buffer. Buffer salts were removed by a rapid dip in ice-cold distilled water and the sections rapidly air dried. Autoradiograms were generated by apposing the sections alongside with tritium standards to tritium sensitive films for 4 weeks. The films were then developed as described before (Quirion et al., 1981) and ${ }^{3} \mathrm{H} \mathrm{SCH} 23390$ and ${ }^{3} \mathrm{H}$ raclopride binding quantified (fmol/mg tissue wet weight) using computer assisted microdensitometric image analysis system (MCID System, Imaging Research Inc., St. Catherines, Ontario, Canada). Although, the DI radioligand, ${ }^{3} \mathrm{H} \mathrm{SCH}$ 23390, also binds 5HT2 receptors (Bischoff et al., 1986), under the conditions used in this study, this ligand is likely preferentially labeling
D1 receptors (Dawson et al., 1986). Anatomical areas were identificd according to the Paxinos and Watson's atlas (1982). Significant differences between experimental groups ( $n=4$ in each group) were determined by a one-way analysis of variance (ANOVA).

Probe implantation and hippocampal in vivo dialysis. Male SpragueDawley rats $(250-350 \mathrm{gm})$ were anesthetized with sodium nembutal $(50$ $\mathrm{mg} / \mathrm{kg}$ ). Transverse probes (Damsma et al., 1987) were stereotaxically implanted in the dorsal hippocampus and for septally manipulated animals also in the lateral septum (Giovannini et al.. 1994) at coordinates of $3.8 \mathrm{~mm}$ posterior to bregma and $3.5 \mathrm{~mm}$ below the skull for the hippocampus and $0.7 \mathrm{~mm}$ anterior to bregma and $4.5 \mathrm{~mm}$ below the skull for the septum (Paxinos and Watson, 1982). The animals were individually housed and allowed to recover from surgery for $2 \mathrm{~d}$ prior to their use in the in vivo dialysis experiments. Each animal was dialyzed only once.

At the beginning of each dialysis experiment, animals were placed in lidless cages and connected to a BAS microliter syringe pump in a manner as to allow them to freely move in the cages. The probes were perfused for a one hour wash out period at a flow rate of $2.34 \mu \mathrm{l} / \mathrm{min}$ with an Ungerstedt-Ringer solution $(127 \mathrm{~mm} \mathrm{NaCl}, 2.5 \mathrm{mM} \mathrm{KCl}, 1.0$ $\mathrm{mM} \mathrm{MgCl} 2,1.3 \mathrm{mM} \mathrm{CaCl}, \mathrm{pH} 7.4$ ) containing $5 \mu \mathrm{M}$ neostigmine bromide, a cholinesterase inhibitor. Twenty five minute dialysate fractions were collected into a $1 \mathrm{ml}$ glass vials containing $46 \mu \mathrm{l}$ of $0.1 \mathrm{~N} \mathrm{HCl}$ and $50 \mathrm{pmol}$ of deuterated $\mathrm{ACh}$ as internal standard. Following about $3 \mathrm{hr}$ of baseline hippocampal ACh release. drugs of interest were tested by inclusion in the perfusion Ringer's solution for the remainder of the dialysis experiment. For septally manipulated animals, the drugs of interest were perfused into the septum in a Ringer's solution lacking neostigmine. The samples were frozen immediately and stored at $-80^{\circ} \mathrm{C}$ until assayed by gas chromatography/mass spectroscopy (GC/MS). Following most experiments, probe location was verified by standard histological examination of the brain.

In the experiment designed to evaluate the potential diffusion of the locally applied drugs, the in vivo dialysis setup was as described above for hippocampally manipulated animals except that 'H SCH 23390 (1 $\mu \mathrm{M})$ was used and no samples were collected. The animals were sacrificed immediately following the termination of the experiment. Twenty micrometer slices of the brains of these animals were exposed to tritium sensitive Hyperfilms for $10 \mathrm{~d}$.

GC/MS analysis of ACh. ACh content of the dialysate fractions was determined by GC-MS as described in detail by Marien and Richard (1990). Briefly, frozen samples were lyophilized overnight, reconstitutcd in $250 \mu \mathrm{l}$ acctonitrile, capped, heated at $80^{\circ} \mathrm{C}$ for $30 \mathrm{~min}$, and dried under a gentle stream of nitrogen gas. Quaternary amines present in the samples were demethylated by adding $250 \mu \mathrm{l}$ sodium benzene thiolate solution $(160 \mathrm{mg}$ in $18 \mathrm{ml}$ of redistilled methyl ethyl ketone and $35 \mu \mathrm{l}$ glacial acetic acid) under a flow of nitrogen and reacting at $80^{\circ} \mathrm{C}$ for $45 \mathrm{~min}$. Samples were then extracted into $35 \mu \mathrm{l}$ citric acid and washed twice with $250 \mu \mathrm{l}$ pentane. Finally the samples were extracted into 80 $\mu l$ of ethyl acetate and concentrated down to 3-5 $\mu \mathrm{l}$ volume before being injected in to the GC-MS (Hewlett-Packard 5987b). The demethylated derivatives of $\mathrm{ACh}$ were analyzed by selective ion monitoring of 132 atomic mass units (amu) for endogenous and 136 amu for the internal standard, ${ }^{2} \mathrm{H}_{4}-\mathrm{ACh}$.

The amount of endogenous $\mathrm{ACh}$ in each dialysate was calculated (Jenden and Hanin, 1974) from the peak area ratio of endogenous versus deuterated internal standard. Calculations were not corrected for the recovery of $\mathrm{ACh}$ by each dialysis probe. Sample $\mathrm{ACh}$ content was expressed as a percentage of average baseline (eight sample collections preceding drug infusion). Significant differences between experimental groups were determined by a one-way analysis of variance (ANOVA).

\section{Results}

Effect of fimbriaectomy on hippocampal D1 and D2 receptor binding sites

A significant loss $(18.2 \%, p=0.0038)$ of $\mathrm{Dl} /{ }^{3} \mathrm{H} \mathrm{SCH} 23390$ binding was observed in the molecular layer of the dentate gyrus of the ipsilateral hippocampus in lesioned animals $(29.9 \pm 0.8$ vs $36.6 \pm 1.1 \mathrm{fmol} / \mathrm{mg}$ tissue wet weight) (Fig. $1 A, B$ ). No detectable differences were observed in ${ }^{3} \mathrm{H} \mathrm{SCH} 23390$ ) binding in $\mathrm{CAI}, \mathrm{CA} 2$, and $\mathrm{CA} 3$ subfields between the ipsi- and contralateral hippocampi of fimbriaectomized rats (Fig. $1 A, B$ ). ${ }^{3} \mathrm{H} \mathrm{SCH}$ 23390 binding levels were similar in the hippocampus of sham 
A

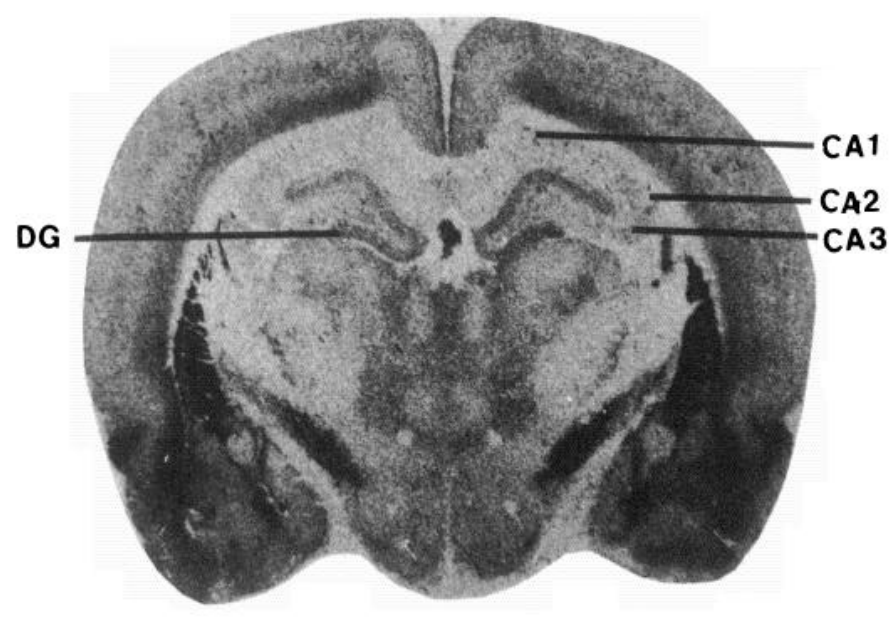

C

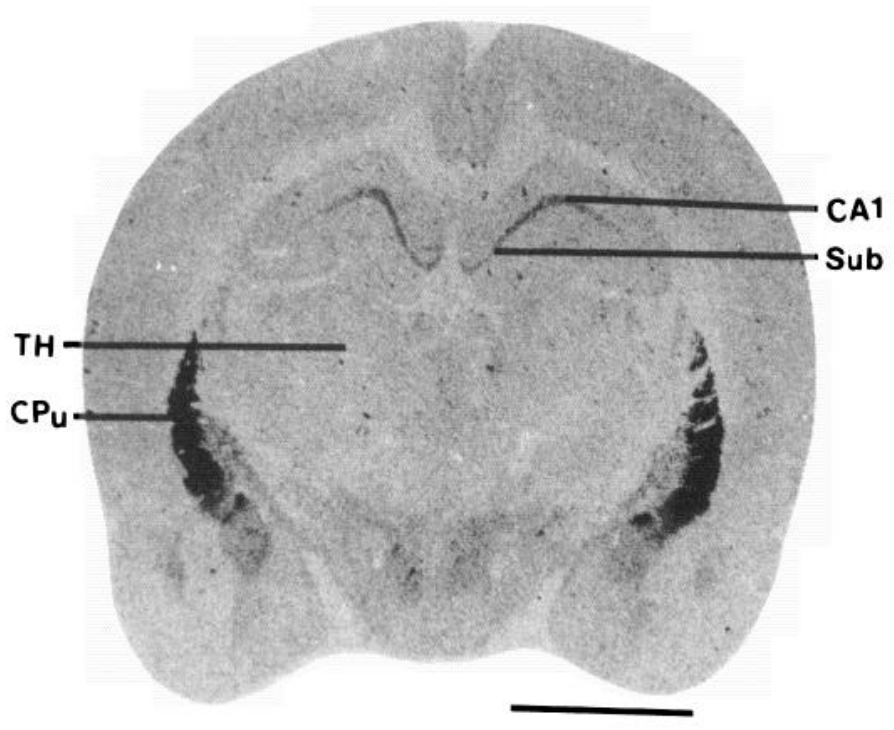

B

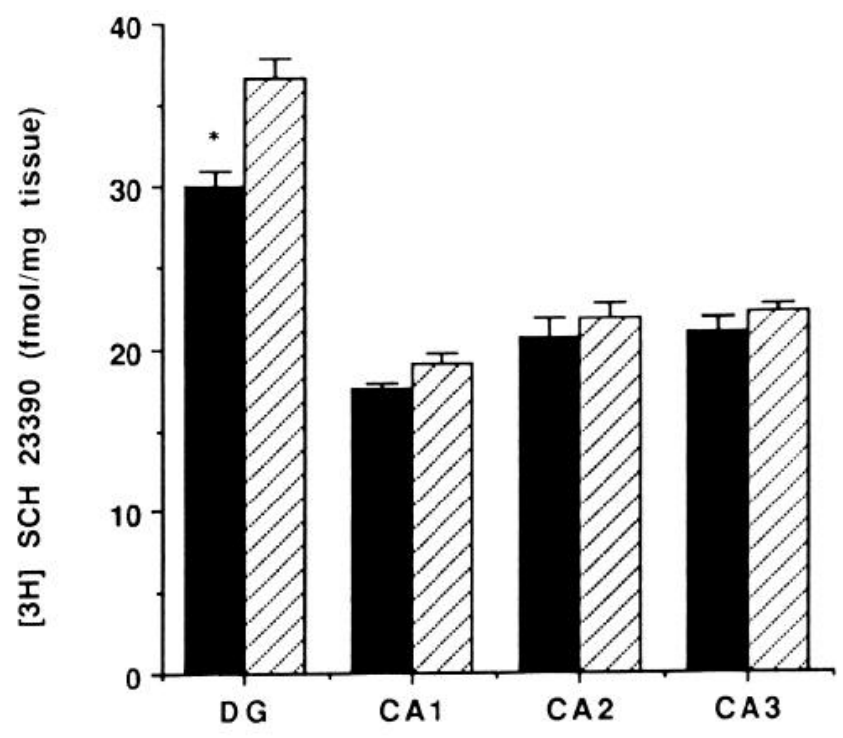

D

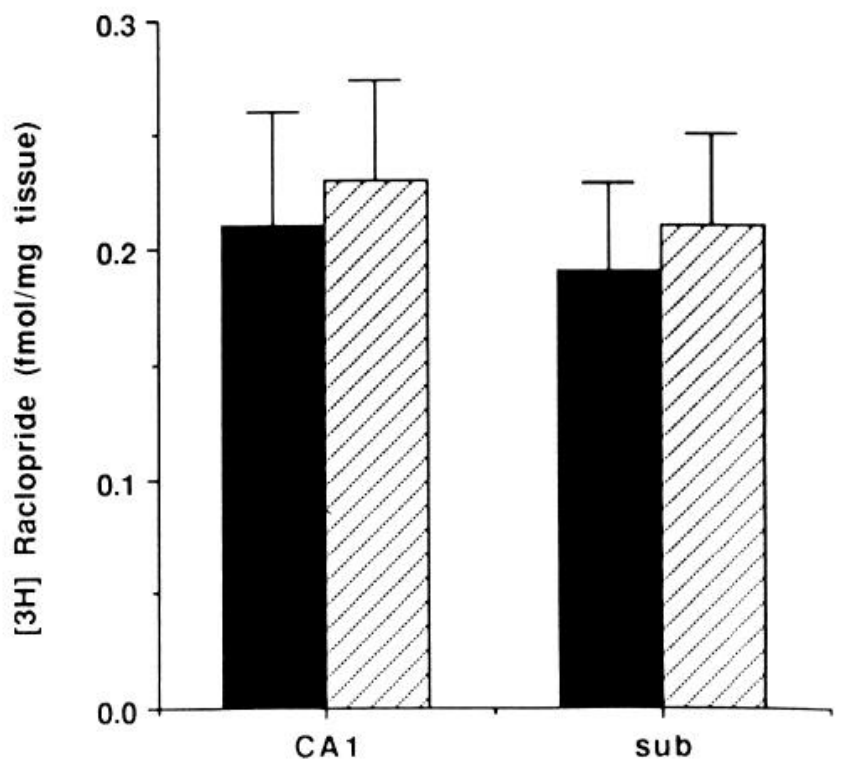

Figure 1. Effect of fimbriaectomy on hippocampal D1/ ${ }^{3} \mathrm{H} \mathrm{SCH} 23390$ and $\mathrm{D} 2 /{ }^{3} \mathrm{H}$ raclopride binding. Data represent mean \pm SEM from four different animals expresses in $\mathrm{fmol} / \mathrm{mg}$ tissue, wet weight. Sections from unilaterally fimbriaectomized rats were incubated with $1.0 \mathrm{~nm}{ }^{3} \mathrm{H}$ SCH $23390 / \mathrm{D} 1(A, B)$ or ${ }^{3} \mathrm{H}$ raclopride/D2 $(C, D)$ as described in Materials and Methods. Nonspecific binding was defined in the presence of $1 \mu \mathrm{M}$ SCH 23390 or $1 \mu \mathrm{M}(+)$ butaclamol for D1 and D2, respectively. Autoradiograms $(A, C)$ generated by apposing the sections against tritium sensitive films were subsequently quantified $(B, D)$ using computer assisted image analysis system. The histograms represent specific labeling obtained by subtracting nonspecific from total binding. Solid and shaded bars represent the ipsi- and contralateral, respectively. Statistical analysis was evaluated by one-way analysis of variance (ANOVA). ${ }^{*}, p<0.05$; significantly different from nonlesioned contralateral side. The bar equals $2 \mathrm{~cm}$. Abbreviations: $C A$, Ammon's horn; $C P u$, caudate-putamen; $D G$, dentate gyrus; $S u b$, subiculum. 
operated animals as compared to the contralateral hippocampi of the fimbriaectomized animals (data not shown).

Hippocampal $\mathrm{D} 2 /{ }^{3} \mathrm{H}$ raclopride binding was considerably lower than that of $\mathrm{D} 1{ }^{3} \mathrm{H} \mathrm{SCH} 23390$. Using ${ }^{3} \mathrm{H}$ raclopride, the only detectable amount of specific binding in the dorsal hippocampus was observed in the CAl and subicular regions (Fig. $1 C$ ). No differences were seen between ipsi- and contra-lateral hippocampi of unilaterally fimbriaectomized animals (Fig. 1D). Additionally, no detectable changes of either ${ }^{3} \mathrm{H} \mathrm{SCH} 23390$ or ${ }^{3} \mathrm{H}$ raclopride binding levels were observed in the septum or cortical regions as a result of unilateral fimbriaectomy. In all the animals used here, ChAT activity in the ipsilateral hippocampi decreased by $51 \pm 4 \%$ as compared to the contralateral hippocampi or the hippocampus of sham operated animals.

\section{Local dopaminergic receptor modulation of hippocampal ACh} release

The average basal efflux of ACh from the dorsal hippocampus was $4.8 \mathrm{pmol} / 25 \mathrm{~min}(n=52)$. Moreover, there were no appreciable differences in basal ACh release between the various experimental groups studied here. Hippocampal intraprobe administration of the active enantiomer of the selective D1 agonist (+)SKF $38393(10-100 \mu \mathrm{M})$, but not the inactive enantiomer (-)SKF $38393(10 \mu \mathrm{M})$, increased ACh release in a concentration dependent manner (Fig. 2A). The D1 antagonist SCH 23390 ( $110 \mu \mathrm{M}$ ), by itself, had no appreciable effect on hippocampal ACh release in freely behaving animals (Fig. $2 B$ ). However, the coinfusion of the DI antagonist $(1 \mu \mathrm{M})$ with the DI agonist ( 10 $\mu \mathrm{M}$ ) blocked the stimulatory effect of the latter (Fig. $2 C$ ).

Under the conditions used here, neither the D2 agonist quinpirole $\mathrm{HCl}(1-10 \mu \mathrm{M})$ (Fig. $3 A$ ) nor the D2 antagonists sulpiride (1-10 $\mu \mathrm{M})$ (Fig. $3 B$ ) or eticlopride $(10 \mu \mathrm{M}$, data not shown) significantly modified hippocampal ACh release. Interestingly, when infused in to the lateral septum neither the D1 nor D2 drugs had an effect on hippocampal ACh release (Fig. 4). No appreciable obvious behavioral sequeleae (locomotion, sniffing, grooming, etc.) were induced by these dopaminergic drugs administered via the probe.

\section{Diffusion of hippocampally infused ${ }^{3} \mathrm{H}$ SCH2339O}

${ }^{3} \mathrm{H} \mathrm{SCH} 23390(1 \mu \mathrm{M}, 1 \mu \mathrm{Ci})$ infused via the probe for $4 \mathrm{hr}$ showed virtually no diffusion beyond the hippocampal area immediately in contact with the dialysis probe (Fig. 5). Considering that this concentration of the unlabelled D1 antagonist blocked the stimulation of hippocampal ACh release induced by the DI agonist SKF 38393, it suggests that this effect is occurring locally.

\section{Discussion}

A variety of studies have demonstrated the presence of direct dopaminergic innervation into the hippocampus. This innervation is concentrated in the ventral subiculum, in particular in the presubiculum (Verney et al., 1985). Hippocampal D1 receptors, on the other hand, are mainly located in the molecular layer of the dentate gyrus and the dorsal hippocampus (Dawson et al., 1986; Grilli et al., 1988; Tiberi et al., 1991). In the present study, we observed that a significant portion of $D 1$ receptors in the molecular layer of the dentate gyrus was lost following fimbriaectomy. This suggests that a proportion of hippocampal DI receptors are located presynaptically on afferent terminals. Moreover, a concomitant reduction in hippocampal ChAT activity was observed as a result of the lesion. Considering that a
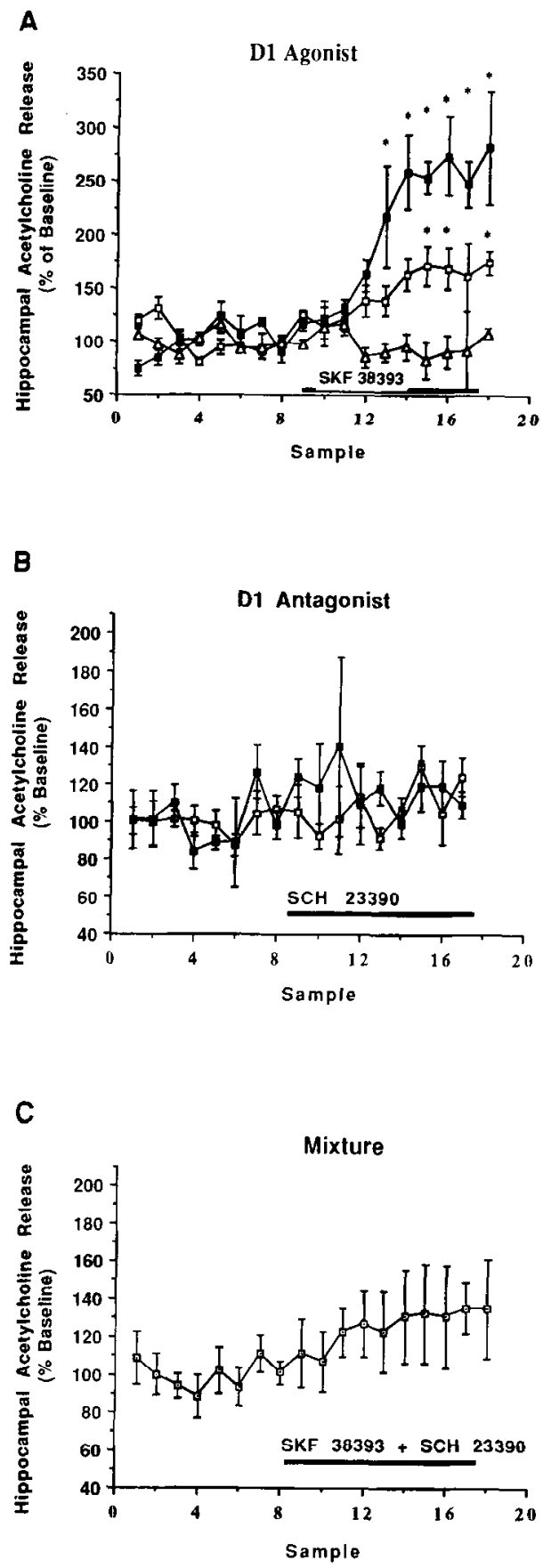

Figure 2. Effects of the infusion of the D1 agonist (+)SKF 38393 [A: $10 \mu \mathrm{M}, \square ; 100 \mu \mathrm{M}, \square$; or its inactive enantiomer (-)SKF 3839310 $\mu \mathrm{M}, \triangle \mathrm{J}$, the Dl antagonist SCH $23390(B: 1 \mu \mathrm{M}, \square ; 10 \mu \mathrm{M}, \square)$, or their combination $(C: 10 \mu \mathrm{M}(+) \mathrm{SKF} 38393$ and $1 \mu \mathrm{M}$ SCH 23390) on hippocampal ACh efflux. Data represent mean \pm SEM $(n=4$ for each concentration). Following baseline determination, Ringer's solution containing the drug of interest was perfused through the probe implanted in the hippocampus for the period indicated by the black bars (upto 4 hr). Dialysate ACh content, measured by GC-MS, is expressed as a percent of baseline. Baseline was calculated from the average of eight samples preceding drug infusion. Statistical evaluation was evaluated by one-way analysis of variance (ANOVA). $*, p<0.001$; significantly different from baseline. Only the D1 agonist induced significant effects $(A)$ that were blocked by the a coinfusion of the antagonist $(C)$. 


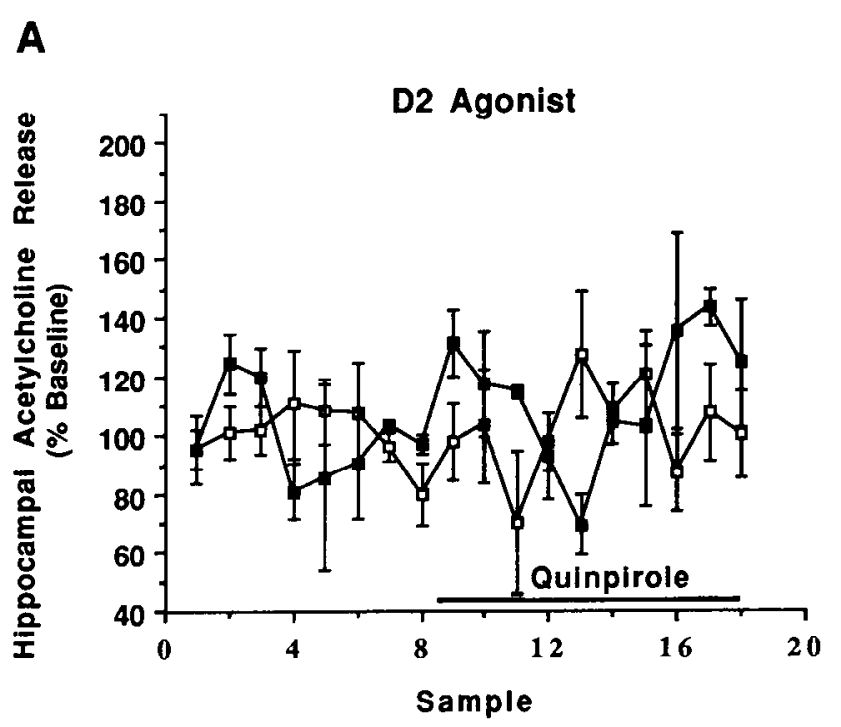

B

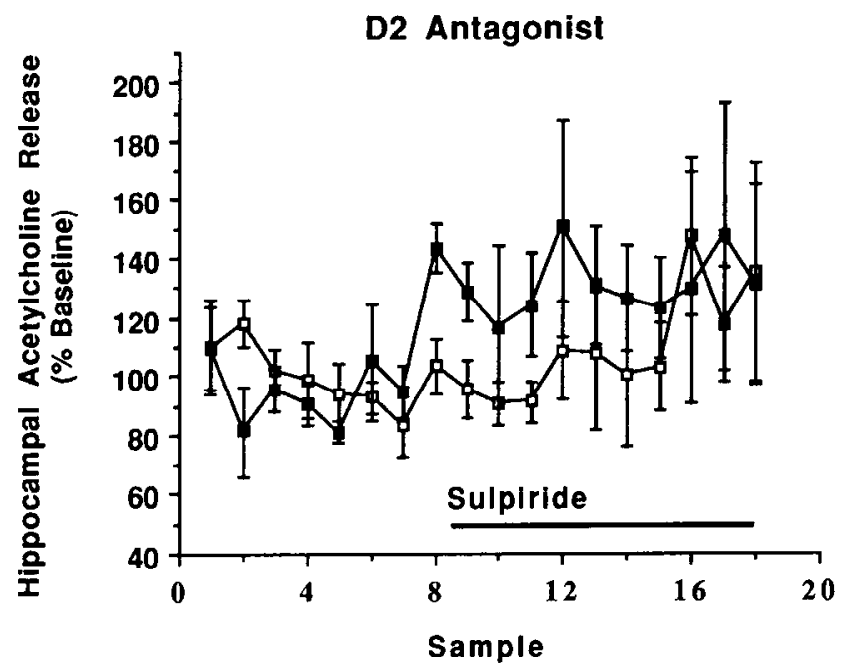

Figure 3. Effects of the infusion of the D2 agonist quinpirole $(A: 1$ $\mu \mathrm{M}, \square ; 10 \mu \mathrm{M}, \square)$ and the D2 antagonist sulpiride $(B: 1 \mu \mathrm{M}, \square ; 10$ $\mu \mathrm{M}, \boldsymbol{\square})$ on hippocampal ACh efflux. Data represent mean \pm SEM ( $n$ $=4$ for each concentration). Following baseline determinations, Ringer's solution containing the drug of interest was perfused through the probe implanted in the hippocampus for the period indicated by the solid hars (up to $4 \mathrm{hr}$ ). Dialysate ACh content, measured by GC-MS, is expressed as a percent of baseline. Baseline was calculated from the average of eight samples preceding drug infusion.

et al., 1985), it is logical to assume that at least some of the lost D1 receptors are located on cholinergic nerve terminals. Interestingly, in senile dementia of the Alzheimer's type (SDAT), a marked reduction in hippocampal $\mathrm{D} 1$ receptors has been reported (Cortes et al., 1988), with the highest loss (89\%) seen in the molecular layer of the dentate gyrus. It is well known that one of the hallmarks of SDAT is the destruction of basal forebrain cholinergic neurons which, in part, project to the hippocampus (Davies and Maloney, 1976; Whitehouse et al., 1982; Coyle et al., 1983). Therefore, in agreement with these studies, the re-

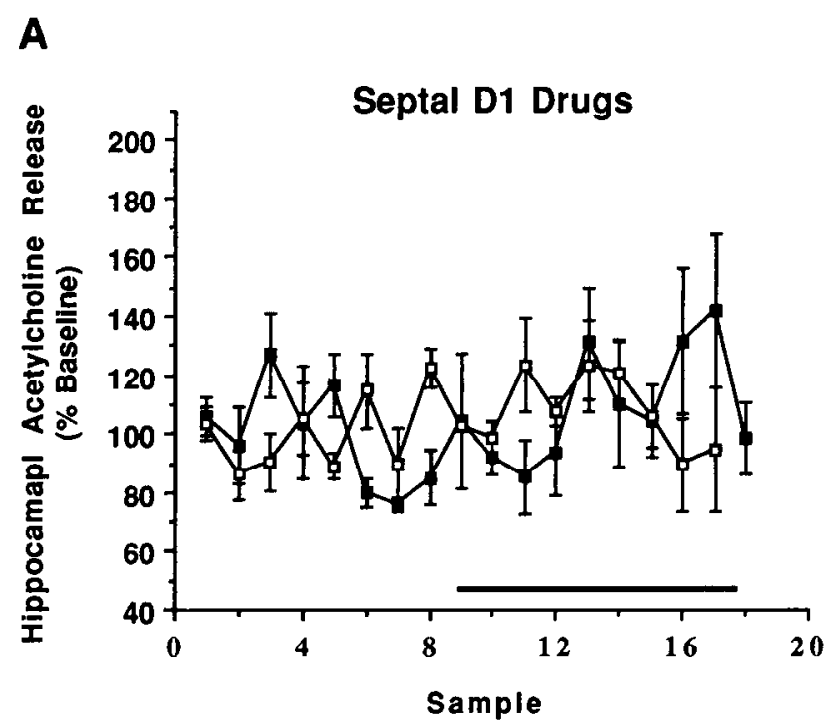

B

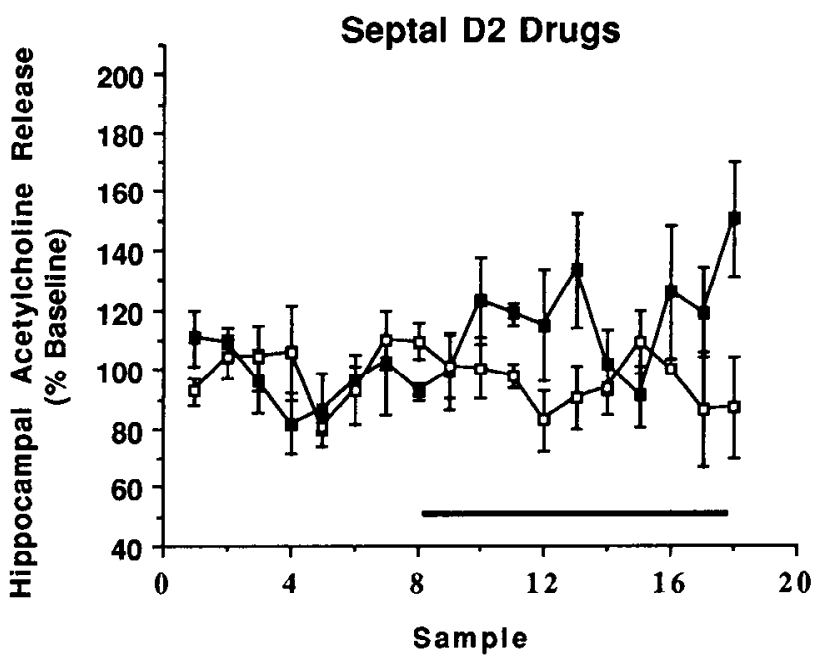

Figure 4. Effects of the septal infusion of the DI ligands ( $A$ : SKF $3839310 \mu \mathrm{M}, \square$; SCII $2339010 \mu \mathrm{M}, \square$ ) and the D2 ligands ( $B$ : quinpirole $10 \mu \mathrm{M}, \square$; sulpride $10 \mu \mathrm{M}, \square$ ) on hippocampal ACh efflux. Data represent mean $\pm \operatorname{SEM}$ ( $n=4$ for each ligand). Following baseline determinations, Ringer's (minus neostigmine) solution containing the drug of interest was perfused through the probe implanted in the septum for the period indicated by the black bars (up to $4 \mathrm{hr}$ ). Samples were collected from the probe implanted in the dorsal hippocampus. Dialysate ACh content, measured by GC-MS, is expressed as a percent of baseline. Baseline was calculated from the average of eight samples preceding drug infusion.

duction in hippocampal D1 receptors observed here could be due to the loss of presynaptically located receptors resulting from the cholinergic denervation. Nevertheless, the possibility that some of these DI receptors are located on afferents other than cholinergic that are contained within the fimbria-fornix projection cannot be excluded solely on the basis of the present experiments.

D2 receptors, on the other hand, are found in the hippocampus 
A

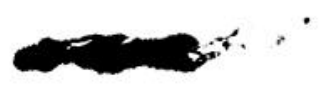

B

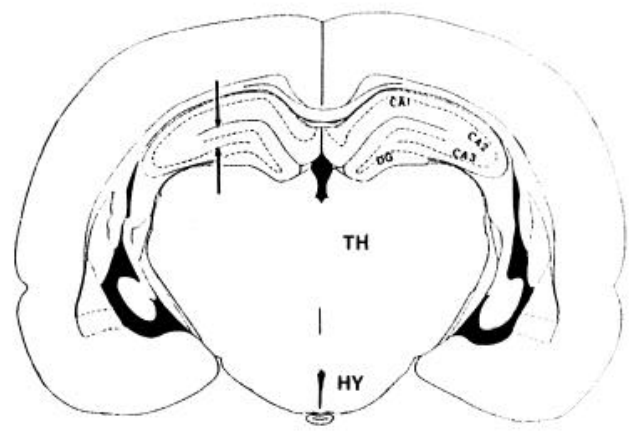

Figure 5. Diffusion of trans-hippocampally infused ${ }^{3} \mathrm{H}$ SCH 23390 in brain parenchyma. ${ }^{3} \mathrm{H}$ SCH 23390 (1 $\mu \mathrm{M}, 1 \mathrm{mCi} / \mathrm{mmol}$ ) was perfused for 4 $\mathrm{hr}$ in the dorsal hippocampus as described in Materials and Methods; 20 $\mu \mathrm{m}$ brain sections from these animals were exposed to tritium sensitive films and photomicrographs taken. $A$ shows the extent of diffusion of the radioactive material; $B$, a schematic representation of the section in $A$. The arrows mark the location of the dialysis probe. It is rather evident that diffusion was minimal and the infused radioactivity remained in close proximity to the dialysis probe. Abbreviations: $C A, \mathrm{Am}-$ mon's horn; $D G$, dentate gyrus; $H Y$, hypothalamus; $T H$, thalamus. in very low amounts compared to D1 receptor levels (Fig. 1D). In the dorsal hippocampus, $\mathrm{D} 2 /{ }^{3} \mathrm{H}$ raclopride binding sites are mainly located in the $\mathrm{CAl}$ and subiculum regions (Fig. $1 C$ ). In the present study, no alteration in hippocampal D2 receptor densities were observed following fimbriaectomy. It would thus appear that this dopamine receptor subtype is not directly associated with the septo-hippocampal cholinergic nerve projection.

Recently, the technique of in vivo dialysis has been used to study the possible regulation by dopaminergic drugs of the septo-hippocampal cholinergic pathway. Systemic administration of dopaminergic drugs has shown that dopamine potentially stimulates hippocampal $\mathrm{ACh}$ release via both D1 and D2 receptor subtypes (Imperato et al., 1993) or the D1 subtype alone (Day and Fibiger, 1994) in young animals, and at least via D1 receptors in aged-memory impaired rats (Hersi et al., 1994). A number of possible loci exist for this apparent interaction between $\mathrm{DA}$ and $\mathrm{ACh}$. Given the direct dopaminergic innervation of the hippocampus and the putative localization of D1 receptors on hippocampal terminals (see above), a direct modulation of hippocampal ACh release by DA drugs is a likely possibility.

The D1 receptor agonist (+)SKF 38393 applied directly into the hippocampus via the dialysis probe stimulated, in a concentration dependent, $\mathrm{ACh}$ release. This effect was blocked by the D1 antagonist SCH 23390 while the inactive stereoisomer (-)SKF 38393 had no effect by itself, attesting to the specificity of the effect for the D1 receptor family. SCH 23390 infused alone in the dialysis probe did not alter hippocampal ACh levels. These findings suggest that the D1 receptors located in the dorsal hippocampus can enhance $\mathrm{ACh}$ release and that this action is likely phasic in nature, in view of the lack of effect of the D1 antagonist alone.

A question arises, however, as to the extent of diffusion of locally applied drugs in the in vivo dialysis paradigm used here. This is especially pertinent considering the relatively long period of drug infusion. Administration of ${ }^{3} \mathrm{H}$ SCH 23390 under conditions identical to those used for the nonradioactive drugs, showed that diffusion is rather minimal and that the ligand is mostly, if not exclusively, found in the area surrounding the dialysis probe (Fig. 5). Thus, it would appear that local interaction can account for the effects of D1 drugs on hippocampal ACh release as observed in the present study or following systemic administration (Imperato et al., 1993; Day and Fibiger, 1994; Hersi et al., 1994).

In contrast to D1 drugs, neither the stimulation nor the blockade of D2 receptors by local, intraprobe infusion of prototypical drugs into the dorsal hippocampus had any effect on ACh release.

Another possible locus for $\mathrm{ACh} / \mathrm{DA}$ interaction is the lateral septal area. Dopaminergic projections arising from the VTA and terminating in the lateral septum were postulated to interact with the cholinergic cell bodies of the medial septum that give rise to the cholinergic septo-hippocampal pathhway (Wood, 1985). In the present study, the manipulation of neither D1 nor D2 receptors in the septal area had any effect on hippocampal ACh release. Thus, it would appear that dopamine stimulates hippocampal ACh release by acting on D1 receptors located in the hippocampus. However, although the lesion data presented here suggests that these D1 receptors are located on cholinergic terminals, the possibility of transsynaptic action involving interneurons or other noncholinergic afferents cannot be ruled out at the present time.

In the classical view of the synapse, a close juxtaposition must exist between the nerve fiber terminals enriched with a given neurotransmitter and its postsynaptic receptors. However, this is clearly not always the case and may even be the exception (Beaudet and Descarries, 1978). Discrepancies between the localization of receptors and the distribution of the relevant neurotransmitter has been referred to as the mismatch issue (Kuhar, 1985; Herkenham, 1987). In the present situation, the hippocampal dopaminergic innervation, arising mainly from the VTA and the substantia nigra, is mostly restricted to the ventral hippocampus (Verney et al., 1985). In contrast, hippocampal dopaminergic receptors are predominantly found in the dorsal hippocampus (Dawson et al., 1986; Grilli et al., 1988; Tiberi et al., 1991; this study). Interestingly, however, more than $40 \%$ of the dopamine present in the hippocampus has been proposed to be located within dorsal noradrenergic terminals (Bischoff et al., 1979). It may be conceivable that, under certain conditions, dopamine and noradrenaline may be coreleased from the terminals of the latter present in the dorsal hippocampus. It is also tempting to suggest that crossover between neurotransmitters may exist to partly account for the apparent mismatches. For instance, under excessive cell firing conditions, the release of noradrenaline in quantities large enough to saturate its own receptors may lead to the binding of this neurotransmitter to other related receptor families such as those for dopamine. In this way, a secondary level of complexity would be added to code for signal strength and more effective transmission.

Another intriguing possibility to account for apparent ligandreceptor mismatches is known as volume transmission (VT). In 
contrast to the classical synaptic mode of signal transmission, VT refers to the diffusion of chemical signals in the extracellular fluid. $\Lambda$ neurotransmitter could thus act at a considerable dis tance from its site of release (for a recent review, see Benfenati and Agnati, 1991). For example, it has been reported that when transient parkinsonism is induced in cats following MPTP administration, dopamine released from spared ventral striatum terminals can diffuse over a distance of $5.5-7.0 \mathrm{~mm}$ to the more extensively denervated dorsolateral striatum (Schneider et al., 1994). Similarly, dopamine released from fiber terminals located in the ventral hippocampus could diffuse to the dorsal part where the dopaminergic D1 receptors are mostly found. However, direct evidence in support of this possibility have yet to be provided. Interestingly, D1 receptors have, in the past, been linked with volume transmission in areas such as the median eminence and globus pallidus (Fuxe et al., 1988). In any case, it is evident from the data reported here that the activation of D1 receptors present in the dorsal hippocampus can modulate $\mathrm{ACh}$ release and are hence fully functional.

Finally, it should be added that the physiological significance of the dopaminergic system in the hippocampus is not yet clear. Intrahippocampal injections of dopamine receptor agonists evoke theta rhythms in hippocampal electroencephalograms (Smialowski, 1985). This type of rhythmic oscillation is known to occur during periods of learning (Winson, 1978). Moreover, during theta oscillation, hippocampal synapses are in a state of heightened plasticity and the stimulatory requirements for the induction of long term potentiation (LTP) are markedly reduced (Huerta and Lisman, 1993). Interestingly, a well established role of the hippocampal cholinergic nerve terminals is to elicit theta rhythms (Bland, 1986). Most recently, dopamine was reported to modify LTP in the Schaffer collateral pathway of the rat hippocampus via Dl receptors (Huang and Kandel, 1995). In addition, mnemonic deficits in aged rats can be attenuated by DI receptor agonists, and this effect was proposed to be mediated by the release of $\mathrm{ACh}$ in the hippocampus (Hersi et al., 1994). Therefore, it appears that a role for DA in the hippocampus could, at least in part, be associated with learning and memory, likely via the modulation of hippocampal cholinergic functions.

In summary, a certain proportion of hippocampal Dl receptors appears to be located directly on septo-hippocampal cholinergic nerve terminals. Moreover, in vivo hippocampal ACh release is facilitated by the local stimulation of D1 but not D2 receptors. Recent data have clearly shown that the Dl receptor family comprises both the $\mathrm{d} l$ and $\mathrm{d} 5$ subtypes (see introductory section). At present, it is unclear which of these two subtypes is involved in the modulation of hippocampal $\mathrm{ACh}$ release as selective probes have yet to be developed to discriminate between these members of the D1 receptor family. Other strategies such as the use of functional receptor antibodies or oligonucleotide antisenses would have to be used.

\section{References}

Araujo DM, Lapchak PA, Robitaille Y, Gauthier S, Quirion R (1988) Differential alteration of various cholinergic markers in cortical and subcortical regions of human brain in Alzheimer's disease. J Neurochem 50:1914-1923.

Beaudet A, Descarries L (1978) The monoamine innervation of rat cerebral cortex: synaptic and nonsynaptic axon terminals. Neuroscience 3:53-67.

Benfenati F, Agnati LC (1991) Communication and computation in the central nervous system. Funct Neurol 6:202-209.

Bischoff S, Scatton B, Korf J (1979) Biochemical evidence for neu-
Utransmilter role of dopamine in the rat hippocampus. Brain Res 165:161-165.

Bischoff S, Bittiger H, Krauss J (1980) In vivo ${ }^{3} \mathrm{H}$ spiperone binding to the rat hippocampal formation. Involvement of dopamine receptors. Eur J Pharmacol 68:305-315.

Bischoff S, Heinrich M, Sonntag JM, Krauss J (1986) The D1 dopamine receptor antagonist SCH 23390 also interacts potently with brain serotonin (5HT2) receptors. Eur J Pharmacol 129:367-370.

Bland BH (1986) The physiolngy and pharmacology of hippocampal formation of theta rhythms. Prog Neurobiol 26:1-54.

Bruinink A, Bischoff S (1986) Detection of dopamine receptors in homogenates of rat hippocampus and other brain arcas. Brain Res 386:78-83.

Butcher LL, Woolf NJ (1986) Central cholinergic system: synopsis of anatomy and overview of physiology and pathology. In: The biological substrata of Alzheimer's disease (Schlemiel. Wechsler, eds), pp 73-86. New York: Academic.

Cortes R, Probst A, Palacios JM (1988) Decreased densities of dopamine D1 receptors in the putamen and hippocampus in senile dementia of the Alzheimer's type. Brain Res 475:164-167.

Costa E, Panula P, Thompson HK, Cheney DL (1983) The trans-synaptic regulation of the septohippocampal pathway. Life Sci 32:165179.

Coyle JT, Price DL, Delong MR (1983) Alzheimer's disease: a disorder of cortical cholinergic innervation. Science 219:1184-1190.

Damsma G, Westerink, BHC, de Vries JB, Van den Berg CJ, Horn AS (1987) Measurement of acetylcholine release in freely moving rats by means of automated intracrebral dialysis. J Neurochem 48:15231528.

Davies P, Maloney AJ (1976) Selective loss of central cholinergic neurons in Alzheimer's disease. Lancet 2:1403-1403.

Dawson TM, Gehlert DR, McCabe RT, Barnett A, Wamsley JK (1986) D1 dopamine receptors in the rat brain: a quantitative autoradiographic analysis. J Neurosei 6:2352-2365.

Day JC, Fibiger HC (1994) Dopaminergic regulation of the septohippocampal cholinergic neurons. J Neurochem 63:2086-2092.

Debonnel G, Gaudreau P, Quirion R, de Montigny C (1990) Effects of long term haloperidol treatment on the responsiveness of accumbens neurons to cholecystokinin and dopamine: electrophysiological and radioligand binding studies in the rat. J Neurosci 10:469-478.

Durkin T, Galey D, Micheau J, Beslon H, Jaffard R (1986) The effects of intraseptal injection of haloperidol in vivo on hippocampal cholinergic function in the mouse. Brain Res 376:420-424.

Fibiger HC (1982) Organization and some projections of cholinergic neurons in the mammalian forebrain. Brain Res Rev 4:327--343.

Fonnum F (1969) Radiochemical microassay for the determination of choline acetyltransferase and acetylcholinestrase activities. Biochem J 115:465-472.

Fuxe K, Agnati LF, Cintra A, Andersson P, Eneroth A, Hafstrand M, Goldstein Z (1988) Studies on central D1 receptors role in volume transmission: neuroendocrine regulation and release of noradrenaline. Adv Exp Med Biol 235:83-119.

Galey D, Durkin T, Sifakis G, Kempf E, Jaffard R (1985) Facilitation of spontaneous and learned spatial behaviour following 6-hydroxydopamine lesions of the septum; a cholinergic hypothesis. Brain Res 340:171-174.

Giovannini MG, Mutolo D, Bianchi L, Michelassi A, Pepeu G (1994) NMDA receptor antagonists decrease GABA outflow from the septum and increase acetylcholine outflow from the hippocampus: a mi crodialysis study. J Neurosci 14:1358-1365.

Gribkoff V, Ashe J (1984) Modulation by dopamine of population responses and cell membrane properties of hippocampal CAl neurons in vitro. Brain Res 292:327-338.

Grilli M, Nisoli E, Memo M, Missale C, Spano P (1988) Pharmacological characterization of D1 and D2 dopamine receptors in rat limbocortical areas II; dorsal hippocampus. Neurosci Lett 87:253-258.

Herkenham M (1987) Mismatches between neurotransmitter and receptor localization in brain: observations and implications. Neuroscience 23:1-38.

Hersi AI, Rowe W, Gaudreau P, Quirion R (1994) Dopamine D1 ligands modulate hippocampal acetylcholine release and cognitive abilities in aged memory impaired rats. Soc Neurosci Abstr 20:1023.

Huang YY, Kandel ER (1995) D1/D5 receptor agonists induce a protein synthesis-dependent late potentiation in the CAl region of the hippocampus. Proc Natl Acad Sci USA 92:2446-2450. 
Huerta PI; Lisman JE (1993) Heightened synaptic plasticity of hippocampal CA1 neurons during a cholinergically induced rhythmic state. Nature 364:723-725.

Imperato A, Obinu MC, Gessa GL (1993) Stimulation of both dopamine D1 and D2 receptors facilitates in vivo acetylcholine release in the hippocampus. Brain Res 618:341-345.

Ishikawa K, Ott T, McGaugh J (1982) Evidence for dopamine as a transmitter in the dorsal hippocampus. Brain Res 232:222-226.

Jenden DJ. I Ianin I (1974) Gas chromatographic microcstimation of choline and acetylcholine after $\mathrm{N}$-demethylation by sodium benzenethiolate. In: Choline and acetylcholine; handbook of chemical assay methods (Hanin I, ed), pp 135-150. New York: Raven.

Kebabian JW, Calne DB (1979) Multiple receptors for dopamine. Nature 277:93-96.

Kuhar MJ (1985) The mismatch problem in receptor mapping studies. Trends Neurosci 8:190-191.

Marien MR, Richard JW (1990) Drug effects in the release of endogenous acetylcholine in vivo: measurements by intracerebral dialysis and gas mass spectroscopy. J Neurochem 54:2016-2023.

Mengod G, Villaro MT, Landwehrmeyer GB, Marlinez-Mir MI, Niznik HB, Sunahara RK, Seeman P, O’Dowd BF, Probst A, Palacios JM (1992) Visualization of dopamine D1, D2 and D3 receptors in human and rat brain. Neurochem Int 20(Suppl):S33-S43.

Monsma FJ, Mahan, LC, Mcvittie L D, Gerfen CR, Sibley DR (1990) Molecular cloning and expression of a DI dopamine receptor linked to adenylate cyclase. Proc Natl Acad Sci USA 87:6723-6727.

Niznik HB, Van Tol HHM (1992) Dopamine receptor genes : new tools for molecular psychiatry. J Psychiatr Neurosci 17:158-179.

Paxinos G, Watson C (1982) The rat brain in stereotaxic coordinates. New York: Academic.

Quirion R, Hammer RP Jr, Herkenham M, Pert CB (1981) Phencyclidine (angel dust)/sigma 'opiate' receptor: visualization by tritium sensitive film. Proc Natl Acad Sci USA 78:5881-5884.

Robinson SE, Mathe-Sorenssen D, Wood PL, Commissiong J (1979) Dopaminergic control of the septohippocampal cholinergic pathway. J Pharmacol Exp Ther 208:476-479.

Scatton B, Simon H, Le Moal M, Bishoff S (1980) Origin of dopa- minergic innervation of the rat hippocampal formation. Neurosci Lett 18:125-131.

Schneider JS, Rothblat DS, DiStefano L (1994) Volume transmission of dopamine over large distances may contribute to recovery from experimental parkinsonism. Brain Res 643:86-91.

Seeman P (1980) Dopamine receptors. Pharmacol Rev 32:229-313.

Sibley DR, Monsma FJ (1992) Molecular biology of dopamine receptors. Trends Pharmacol Sci 13:61-69.

Simon H, Le Moal M, Callas A (1989) Efferents and afferents of the ventral tegmental A-10 region studied after local injection of ${ }^{3} \mathrm{H}$ leucine and horseradish peroxidase. Brain Res 178:17-40.

Smialowski A (1985) The effects of intrahippocampal administration of dopamine or apomorphine on EEG of the limbic structure of the rabbit brain. Pol J Pharmacol Pharm 28:579-586.

Smialowski A, Bijak M (1987) Excitatory and inhibitory action of dopamine on hippocampal neurons in vitro: involvement of $\mathrm{D} 2$ and D1 receptors. Neuroscience 23:95-101.

Stanzione P, Calabressi P, Mercuri N, Bernardi G (1984) Dopamine modulates CAl hippocampal neurons by elevating the threshold for spike generation: an in vitro study. Neuroscience 13:1105-1116.

Tiberi M, Jarvie KR, Sivia C, Falardeau P, Gingricl JA, Godinot N, Bertrand L, Yang-feng TL, Fremeau RT, Caron MG (1991) Cloning, molecular characterization and chromosomal assignment of a gene encoding a second D1 dopamine receptor subtype: differential expression pattern in rat brain compared with the DIA receptor. Proc Natl Acad Sci USA 88:7491-7495.

Tucek S (1978) Choline acetyl transferase. In: Acetylcholine synthesis in neurons, p 29. London: Chapman and Hall.

Verney C, Baulac M, Berger B, Alvarez C (1985) Morphological evidence for a dopaminergic terminal field in the hippocampal formation of young and adult rat. Neuroscience 14:1039-1052.

Whitehouse PJ, Price DL, Struble RG, Clark AW, Coyle JT, DeLong MR (1982) Alzheimer's disease and senile dementia: loss of neurons in the basal forebrain. Science 215:1237-1239.

Winson J (1978) I oss of hippocampal theta rhythm result in spatial memory deficit in the rat. Science 201:160-163.

Wood PL (1985) Pharmacological evaluation of GABAergic and glutamergic inputs into the nucleus basalis-cortical and septohippocampal cholinergic projections. Can J Physiol Pharmacol 64:325-328. 